\title{
Note from the Editorial Board
}

Drofessor Stephen Livingstone made a huge and special contribution to the Northern Ireland Legal Quarterly. To commemorate, celebrate and give thanks for Professor Livingstone's contribution, here, for the first time, we collect several of his main articles from our journal. The publication of this special issue is timed to occur with the 2019 Livingstone Lecture, which will take place on Thursday 21 November 2019, School of Law, Queen's University Belfast. We are particularly grateful to Professor John Morison and Professor Kieran McEvoy, two of Professor Livingstone's former colleagues, for their guest editorship of this special issue and for their introduction to it.

The special issue is available open access from now and in perpetuity. We have sought to preserve each individual article in its original format. We hope this special issue, laden with memories, history, and legal commentary that continue to resonate and shape current thinking, will become a key reference point in itself for future scholarship. The special issue serves to remind us of the scope and influence of Professor Livingstone's scholarship, and to extend its reach far into the future.

Dr Mark Flear, Chief Editor, on behalf of the Editorial Board 19 November 2019 
